\title{
UDC 004.942:316.454.54
}

\author{
P. S. NOSOV ${ }^{1 *}$, I. V.PALAMARCHUK ${ }^{*}$, M. S. SAFONOV ${ }^{3 *}$, V. I. NOVIKOV**. \\ ${ }^{1 *}$ Dep. «Navigation and Electronic Navigation Systems», Kherson State Maritime Academy, Ushakov Av., 20, Kherson, Ukraine, \\ 73000, tel. +38 (050) 90906 08, e-mail pason@ukr.net, ORCID 0000-0002-5067-9766 \\ ${ }^{2 *}$ Dep. «Navigation and Electronic Navigation Systems», Kherson State Maritime Academy, Ushakov Av., 20, Kherson, Ukraine, \\ 73000, tel. +38 (050) 90906 08, e-mail pason@ukr.net, ORCID 0000-0001-9161-1592 \\ ${ }^{3 *}$ Dep. «Computer Engineering and Software Engineering», Odessa National Polytechnic University, Kherson Polytechnic Col- \\ lege, Nebesna Sotnia St., 23, Kherson, Ukraine, 73000, tel. +38 (066) 24581 85, e-mail nemko85@ gmail.com, \\ ORCID 0000-0001-9742-8270 \\ 4*Dep. «Shipbuilding and Power Engineering», Admiral Makarov National University of Shipbuilding, Kherson Branch, Ush- \\ akov Av., 44, Kherson, Ukraine, 73022, tel. +38 (095) 36567 08, e-mail vertigogo@i.ua, \\ ORCID 0000-0002-1823-4919
}

\section{MODELING THE MANIFESTATIONS OF THE HUMAN FACTOR OF THE MARITIME CREW}

Purpose. The article investigates the trajectories of the watch team members in maritime transport that lead to a decrease in the level of security. A formal apparatus is proposed, as well as software and hardware to identify the location of members of the watch team during the execution of complex maneuvers. Methodology. In the course of constructing the mathematical model, the most common schemes of interaction of watch members at the time of performing complex maneuvers were considered. The general problem was considered as a series of watchkeeping interactions that solve micro-tasks of ship control at a certain moment. As a result of simulation it is determined that a key role is played by the first mate, who is the most likely to deviate from the instructions, because of excessive activity or passivity in actions. Also, interaction models of members of the watchkeeping service within the framework of a multi-day ship passage are considered. Findings. Research shows that the formation of established interactions depends on the level of experience and qualifications of the members of the watchkeeping service. Overly active relocation of the mate, as well as function duplication of individual members of the watchkeeping service adversely affects the safety level in ship management. Software and hardware tools are proposed that allow identifying the location and movements of the watch team members, indicating deviations from the watchkeeping instructions for maritime transport. Originality. The authors for the first time developed software and hardware for analyzing the movements of the watchkeeping service members, allowing identifying violations of official instructions. Practical value. Based on the developed software and hardware identification of positions and movements of the members of the watchkeeping service, it becomes possible to more effectively manage the process of training navigators during simulator practice on the basis of the navigation simulator NTPRO 5000 at the Kherson State Maritime Academy, Ukraine. These studies can also be useful in studying the discipline «Organization of the crew actions in extreme conditions».

Key words: human factor; behavioral model; teammate interaction; abnormal situations

\section{Introduction}

One of the important stages in the organization of work on maritime transport is the crew formation, taking into account behavioral characteristics at the time of taking managerial decisions. This approach is conditioned by security measures in accordance with international standards and regulations.

During the control of the vessel, both in real conditions and during practice simulations, a number of difficulties arise. They are related to the negative manifestation of the human factor $[1,2$,
10, 14]. Such manifestations are directly reflected in the result of passage of locations and other maneuvers $[11,12]$ at the time of crew control on the captain's bridge. The situation is complicated by the fact that in addition to the factors directly affecting each specialist $[3,8,13]$, factors of influence from the team members exist $[16,4]$. The more complex the task and the features of the location [15], the larger is the amount of information signals that the navigator faces $[9,17]$. At the time of decision-making, the number of such information signals may exceed the perception threshold, which leads to the concentration loss and, as a 
consequence, raises the subjective entropy of the navigator [4]. World practice shows that the human factor remains the most common cause of catastrophes in maritime transport in present day [5].

\section{Purpose}

Thus, the purpose of this article is to analyze the movements of crew members resulting in the safety level decrease during the maritime transport control.

The main purpose of the article is to determine the interactions of navigators leading to a decrease in the safety level during the performance of the watchkeeping service. It should be noted that for a more visual representation of the situations under study, it is necessary to build a mathematical model for the interaction of team members in terms of set theory, group theory, game theory and the theory of formal systems $[6,7]$.

\section{Methodology}

In the conditions of watchkeeping, especially when practicing maneuvers in relation to locations, several members of the watchkeeping duty influence the decision concerning ship control. In some cases, when it is required by the changes in the situation, the captain gives the command to immediately strengthen the watch on the bridge (Figure 1). Typically, this decision is affected by: visibility, weather and sea conditions, the intensity of navigation and other features of the navigation situation. At the same time, the number of members of the watchkeeping duty is increasing, which also contributes a factor capable of adversely affecting the decision of the navigator. To construct a formal model, consider the following scheme for the interaction of watch members. During the maneuvers, the naval officer requests the watch personnel to specify the indications of navigational instruments and other parameters necessary for steering the vessel.

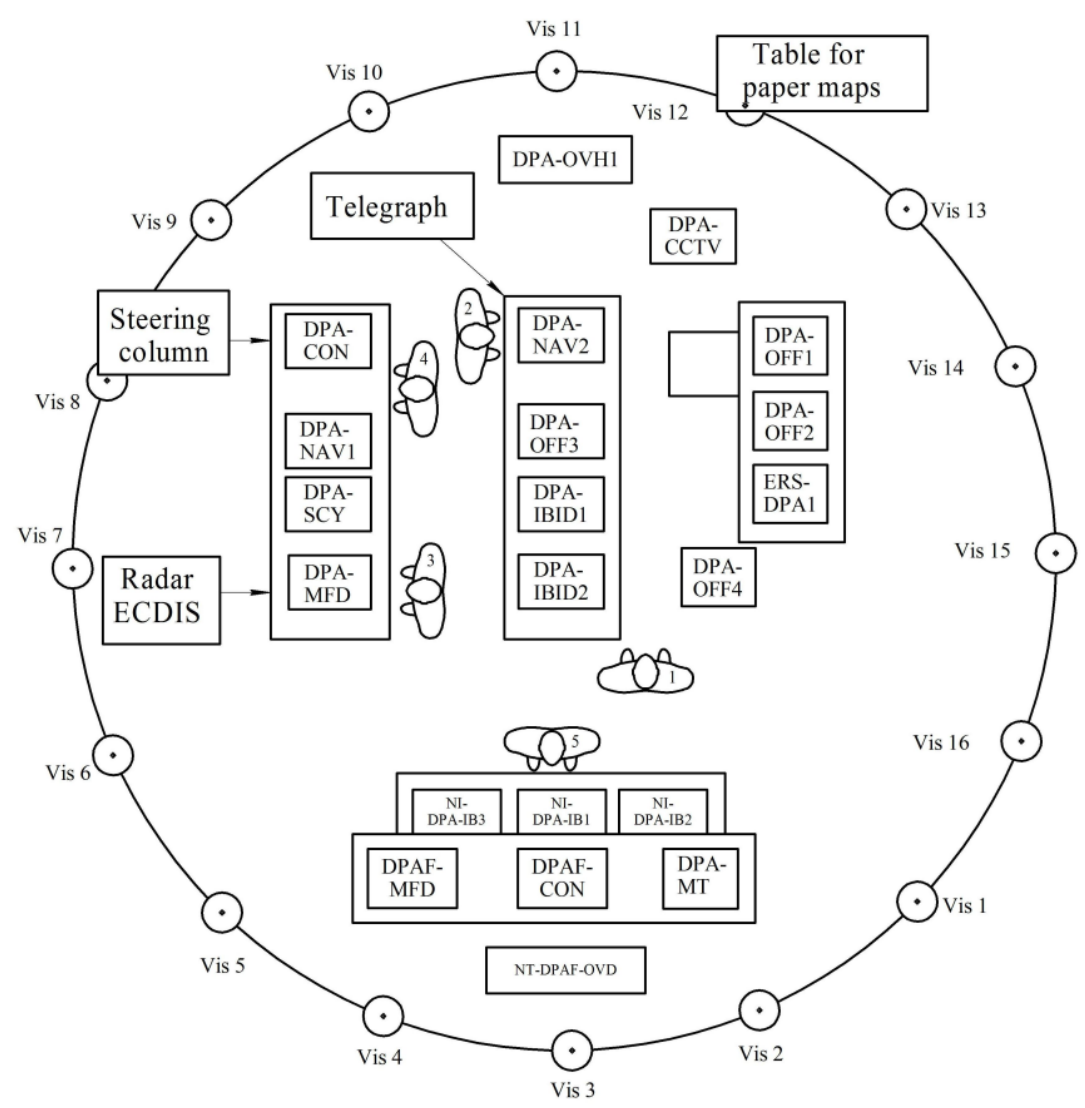

1. Captain

2. First mate

3. Second mate

4. Third mate

5. Boatswain

Fig. 1. The layout of the watchkeeping service's posts 
In this case, local short-time interactions between the members of the watch and the deck officer (captain) occur.

We will assume that two subjects are involved in the interaction: $W$ is the deck officer or captain and $M$ is a member of the watch crew. In this example, the captain instructs before the start of the location passage, and immediately at the time of passage the first mate takes control (Figure 2). Thus, the participant 1 (the captain) does not participate in team interaction, but can prompt the first mate.

Each watch interaction solves the micro-task of steering the vessel at the current moment.

During the passage, the command performs a different kinds of tasks $n$ consisting of a finite sequence of operations depending on the complexity $u_{i}, i=1, \ldots, n$.

Members of the watchkeeping duty $W$ and $M$ are divided into interacting groups $W_{1}, \ldots, W_{\bar{Q}}$ and $M_{1}, \ldots, M_{\bar{S}}$ depending on the level of qualification and experience (Figure 3).

This leads to the formation of groups $W_{R}, M_{S}$ for completing the tasks $n$ and producing results $C_{i}^{R}, \bar{C}_{i}^{S}$.

\section{Creating the model.}

To describe the model, let us set: the set of $I$ different groups of interaction between the watchkeeping members; the numbers $N^{Q}, Q \in I$ of these groups; the set $H=\{\psi\}$ of possible interaction types, where $\psi=\langle Q(1, \psi), \ldots, Q(m(\psi), \psi)\rangle, m(\psi)-$ the number of interactions participants $\psi, Q(i, \psi) \in I$ is the group to which the participant with the number $i$ belongs; function $\vartheta(\psi)$, indicating for $\psi \in H$, the performance value of the micro-tasks, united into interaction $\psi$.

Let us denote the type of interaction corresponding to the individual member of the watch $\mathrm{Q}$, who is not united with anyone using $\langle Q\rangle$ (Figure 4).

At the same time he can be a deck officer with high experience, who ignores the watchkeeping members or an unclaimed watchkeeping member due to low qualification, then $\forall Q \in I\langle Q\rangle \in H, \vartheta(\langle Q\rangle)=0$.

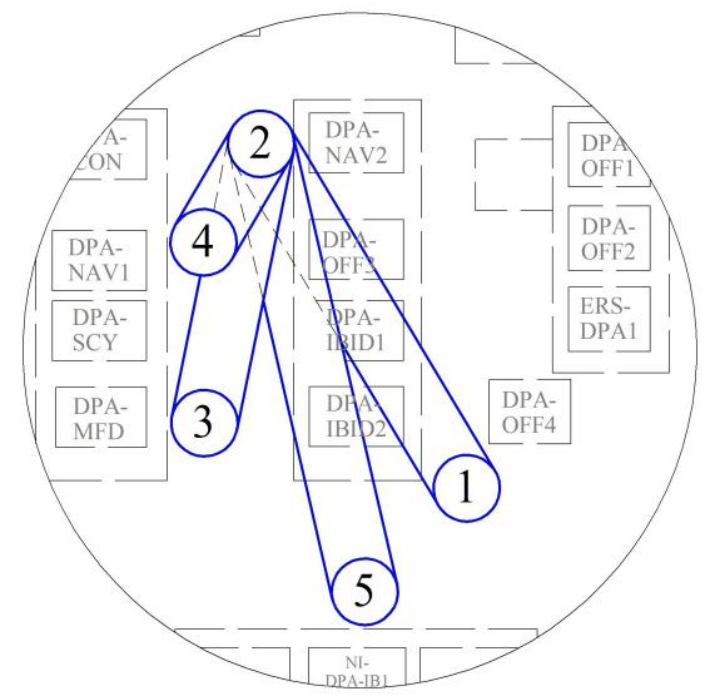

Fig. 2. Planned interaction of the navigators

In this situation the following condition will be true:

$$
\begin{aligned}
H=\{\langle Q\rangle, Q \in I\} & \cup \\
& \cup\left\{\left\langle W_{R}, M_{S}\right\rangle, R=1, \ldots, \bar{Q}, S=1, \ldots, \bar{S}\right\}
\end{aligned}
$$

when $I=\left\{W_{1}, \ldots, W_{\bar{Q}}, M_{1}, \ldots, M_{\bar{S}}\right\}$. Proceeding from the desire of watch members to maximize the vessel controllability, it is natural to assume that when the participants from the groups $W_{R}, M_{S}$ unite, they will give the following result:

$$
i \rightarrow \max _{j=1, \ldots, n}\left(u_{j}-C_{j}^{R}-\bar{C}_{j}^{S}\right) \text { i.e. } \vartheta\left(\left\langle W_{R}, M_{S}\right\rangle\right) .
$$

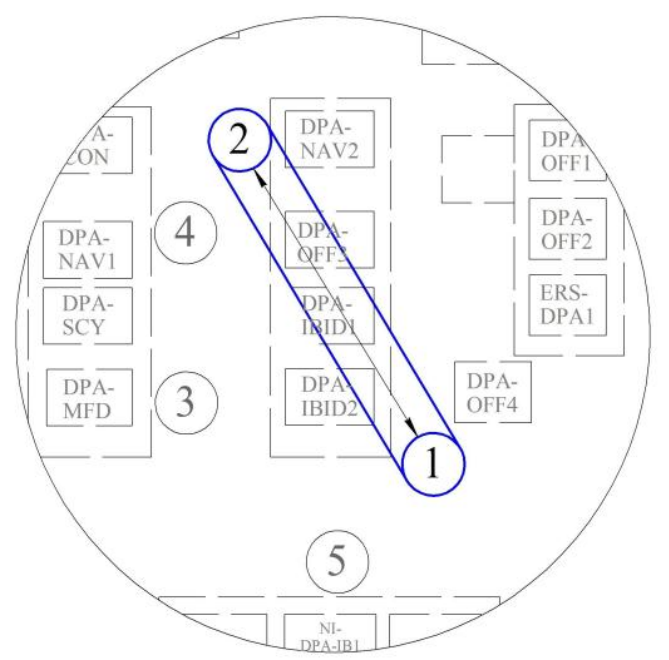

Fig. 3. Interaction of the captain and the first mate 


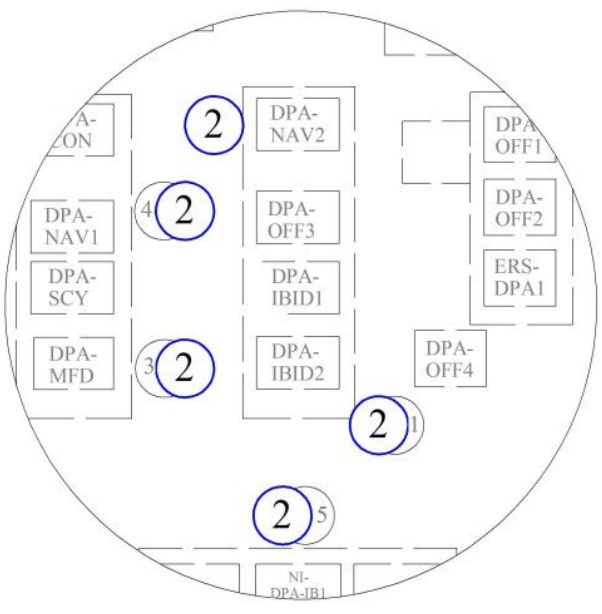

Fig. 4. Doubling of members of the watchkeeping service

The situation when $(Q)$ is a deck officer is fully justified in the conditions of passages with minimal risk, however, in the conditions of complex maneuvering this can lead to serious negative consequences. The case when $(Q)$ is a member of the personnel on duty, whose skills are not trusted by the captain, is unlikely.
Based on Figure 4, the reduction in the safety level can be preceded by the duplication of the functions of the watchkeeping personnel by the watch officer. Even in situations when the maneuver was carried out successfully, the loss of experience by the personnel on duty due to inaction will subsequently lead to negative consequences.

This is justified in cases when the watch officer needs the support of a more experienced navigator, and the acting member of the watchkeeping service does not cope with the task in the allotted time. In such cases, there are unforeseen collisions in the source information for decision-making, uncoordinated actions are possible and as a consequence, the safety level decrease.

\section{Findings}

Initial conditions of the experiment: a team of five men is formed (captain, 1st-3rd mate and boatswain). Before start of the course plotting, the captain instructs on the peculiarities of the terrain and traffic congestion of sea transport (Figure 5).

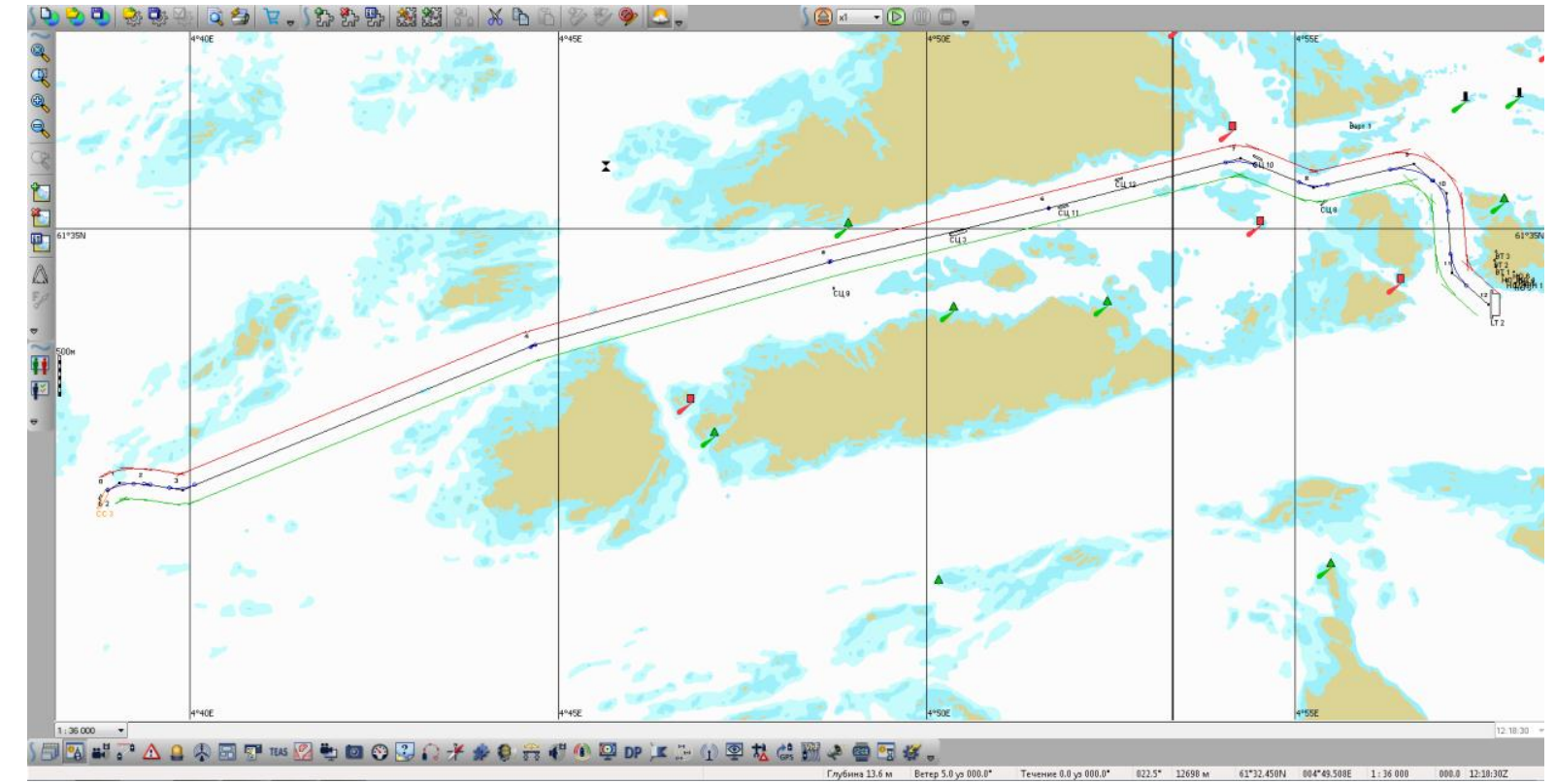

Fig. 5. Vessel's transition path to locations

We describe the interaction of team members formally. Then, $N_{Q}$ when $Q=1, \ldots, \bar{Q}$ and $\tilde{N}_{S}$ when $S=1, \ldots, \bar{S}$ - we will take as the numbers of interaction groups of the personnel on duty with varying qualification in order if its descent.
Analyzing videomaterials on task completion by the watchkeeping members shows that the function of the micro-task performance $\vartheta\left(\left\langle W_{Q}, M_{S}\right\rangle\right)$ decreases monotonically with respect to $Q$ and $S$, i.e. there is a performance increase due to the par- 
ticipation of more qualified member of the watch.

In order to identify location of the members of the watchkeeping service, a computer program was developed that captures their local displacements and synchronizes with the moments of taking managerial decisions.

To determine the location of team members, a three-component system consisting of beacons, wearable sensors and a server is used. Beacons $M_{i}$, $(i \in(1 . . m)$ ), are BLE transmitters (Bluetooth Low Energy), that use the Arduino technology in conjunction with the AT-09 BLE module. Wearable sensors $D_{k}(k \in(1 . . d))$ use the Arduino Mega 2560 plate, heart rate sensor, temperature sensor and the ESP8266 Wi-Fi module.

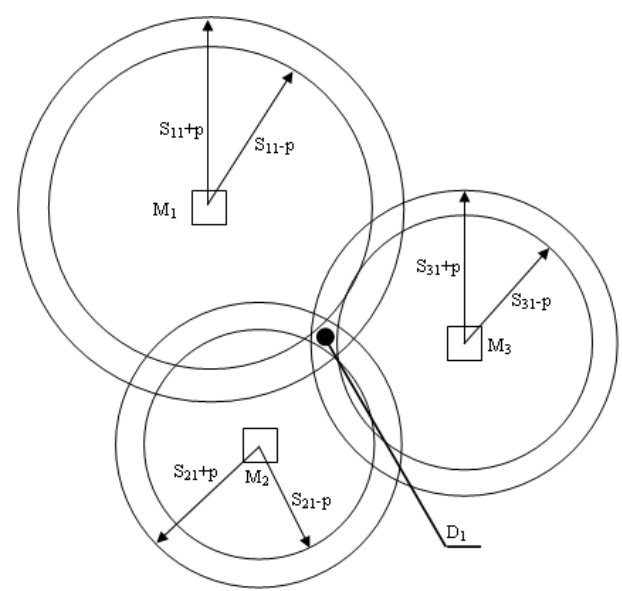

Fig. 6. The scheme for determining the position of the object from distances

All beacons and sensors have their own batteries, which makes them autonomous. $D_{k}$ sensors connect to all beacons Mi by turn and accept from them the packet time $T_{p a c}$. Based on $T_{p a c}$ the distance $S_{i k}$ between the beacon $M_{i}$ and the sensor $D_{k}$ is determined with some error $p$. For unique determination of the location coordinates of the object with sensor, it is necessary to obtain information from at least three beacons.

Increase in the number of beacons will lead to increase in the determination accuracy of the indications. The server receives the data on distance, as well as data from temperature and heart rate sensors over the Wi-Fi network. Also in its memory are written the coordinates of all installed BLEbeacons, which allows accumulating in its database (DB) the coordinates of the object in real time (Figure 6).

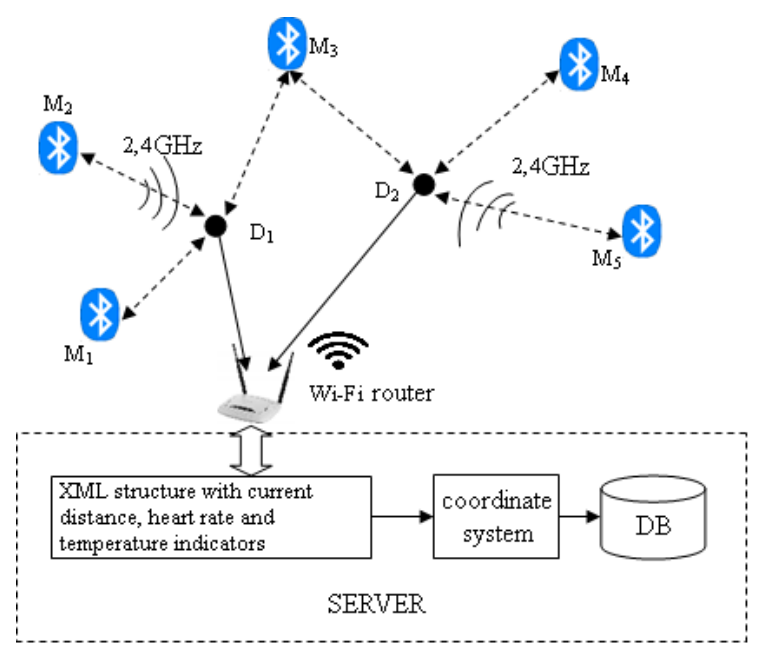

Fig. 7. General scheme of the system operation

Beacons $M_{i}$ can be placed at different heights, as well as the wearable sensors $D_{k}$. Given this fact, there will be an intersection of three spheres. The common part of the intersection will determine the object location with a certain sensor. Increasing the number of beacons will help avoid blind spots and increase the accuracy of the indications.

A special program is installed on the server, which registers the movements of all team members with the connected sensors. All their parameters (coordinates, heart rate and temperature) are stored every few seconds in the database. It is possible to view all movements of team members for conducting behavioral analysis.

The general scheme of the system operation is shown in Figure 7.

The software and hardware complex allows identifying not only the location of members of the watchkeeping service, but also physiological characteristics, such as heart rate and body temperature. These characteristics may indicate the level of stress and mental state of navigators (Figure 8).

Also, in the photo (9) during the experiment it is clear that the small experience of the third mate and the uncertainty in the actions attract the attention of the first mate, who subsequently makes the decision, independently replacing the third mate.

Thus, there is a situation: $\forall L \vartheta\left(W_{Q-1}, M_{S}\right)-\vartheta\left(W_{Q}, M_{S}\right) \Uparrow S$, i.e. maneuverability due to the involvement of a more qualified member of the watch grows faster. Thus, we assume that there are navigators $W_{\bar{Q}+1}$ and $M_{\bar{S}+1}$ of the lowest experience and qualification. 


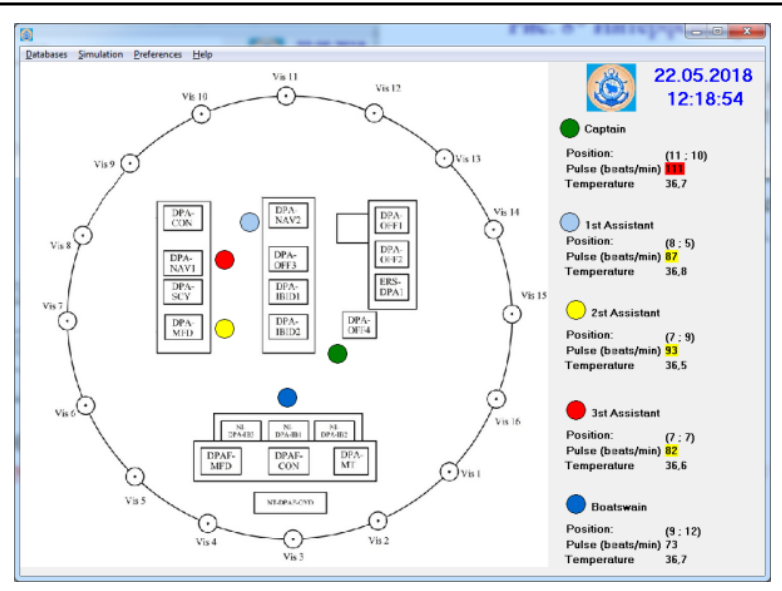

Fig. 8. Program interface

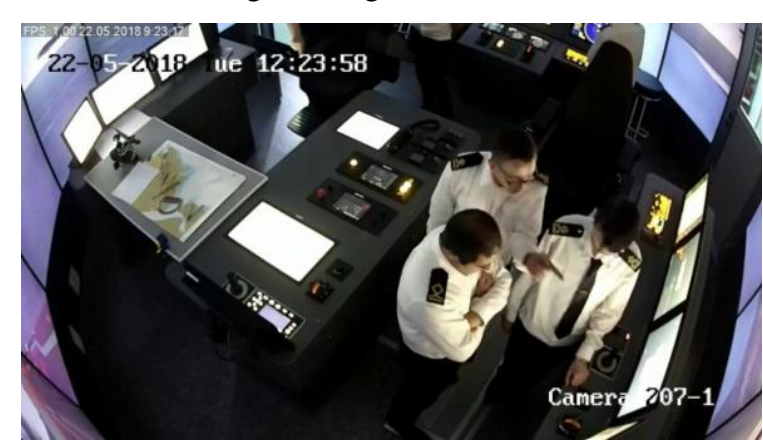

Fig. 9. Doubling of the navigator

$$
\begin{gathered}
\sum_{Q=1}^{\bar{Q}+1} N_{Q}=\sum_{S=1}^{\bar{S}+1} \tilde{N}_{S}: \\
\vartheta\left(W_{Q}, M_{\tilde{S}+1}\right)=\vartheta\left(W_{Q+1}, M_{\tilde{S}}\right)<0 \forall Q, S
\end{gathered}
$$

During the experiment, we define combinations $Q(S)$ and $S(Q)$ of interactions between the watchkeeping members from the conditions:

$$
\begin{gathered}
\sum_{Q=1}^{Q(S)-1} N_{Q}<\sum_{z=1}^{S} \tilde{N}_{z}<\sum_{Q=1}^{Q(S)} N_{Q}, \\
\sum_{S=1}^{S(Q)-1} \tilde{N}_{S}<\sum_{z=1}^{Q} N_{z}<\sum_{S=1}^{S(Q)} N_{S}
\end{gathered}
$$

While: $Q=1, \ldots, \bar{Q}, S=1, \ldots, \bar{S}$.

The most preferred interactions at the time of watchkeeping are of the most experienced members of the watchkeeping service in order of descending qualification, which confirms the existing problem. In this case, two options are possible:

$$
\text { 1. For } \quad \tilde{S} \vartheta\left(W_{Q(\tilde{S})}, M_{\tilde{S}}\right)>0>\vartheta\left(W_{Q(\tilde{S})}, M_{\tilde{S}+1}\right)
$$

deck officer $1, \ldots, \tilde{S}$ is organized into a conversational interaction pair with the watchkeeping member $1, \ldots, Q(\tilde{S})-1$, i.e. an experienced deck officer and unexperienced watchkeeping member. According to the experiment, at a certain time, the deck officer begins to make decisions on his own (Figure 9).

2. For $Q(\tilde{S}), Q(S)$ - is the least experienced deck officer with which the experienced member of the watchkeeping duty $S$ interacts, i.e. members of the watchkeeping duty from the group $S+1$ are united when $S<\tilde{S}$, similarly: $S(Q)$ when $Q<Q(\tilde{S}) ;$ values $p_{Q}, Q=1, \ldots, \bar{Q}, \quad \tilde{p}_{S}, S=1, \ldots, \bar{S}$ are determined from the following condition: $p_{Q}=\tilde{p}_{S}=0 \quad$ when $Q \geq Q(\tilde{S}), S>\tilde{S}, \tilde{p}_{S}=\vartheta\left(W_{Q(S)}, M_{S}\right)-p_{Q(S)} \quad$ and $p_{Q}=\vartheta\left(W_{Q}, M_{S(Q)}\right)-p_{S(Q)} \quad$ when $S \leq \tilde{S}, Q<Q(\tilde{S})$. In situations when $Q$ and $S$ are interchanged, the following is applied:

$$
\tilde{Q} \leq \bar{Q} \quad \vartheta\left(W_{\tilde{Q}}, M_{S(\tilde{Q})}\right)>0>\vartheta\left(W_{\tilde{Q}+1}, M_{S(\tilde{Q})}\right) .
$$

From formal expressions it follows that the most experienced navigators tend to interact with also more qualified members of the watchkeeping duty, in particular, avoiding interaction with unexperienced personnel. In normal circumstances, this does not carry a high risk. However, when performing complex maneuvers, the intensity and content of the information flow from the watchkeeping personnel increases significantly and consequently requires more participation of all members of the watch without exception.

Uncoordinated actions and violation of instructions in the interaction between members of the watchkeeping personnel greatly overloads the navigators' perception, which reduces the safety level of the vessel control. So in the course of the experiment (problem variant No. 2), an abnormal emergency occurred in such a chronology:

1. 13:11:19 - Stop the engine;

2. 13:12:57 -Emergency anchoring for breaking, full astern.

3. 13:13:13 - Touched the ground at the speed of 2.2 knots (Fig. 10). 


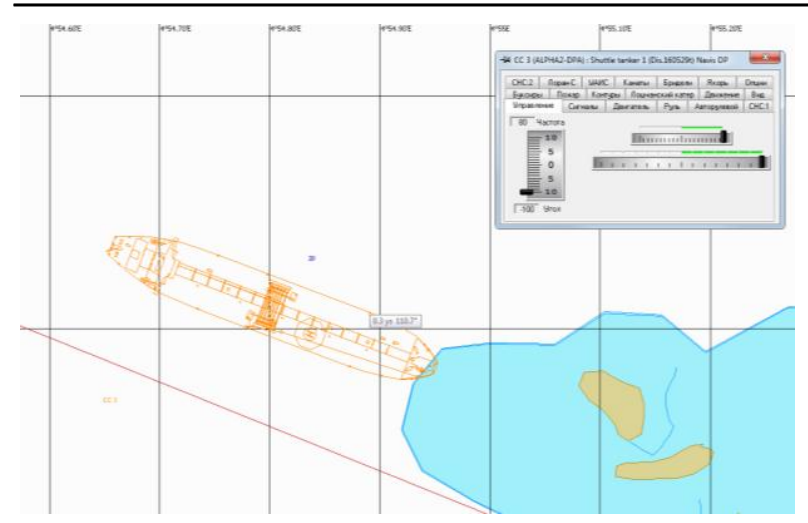

Fig. 10. Catastrophic situation

It should be taken into account that the indicated situations and their formal models are not situational, but have a vector of development and change the structure with discrete time.

Thus, the set $I=\{1, \ldots, m\} \quad I=\{1, \ldots, m\}$ of interactions and the sets $J^{Q}$ of behavior strategies for each interaction $Q \in I$ are given in the model under study. So, from task to task the model is a cycle (passage) of periods $t=0,1,2, \ldots$, in each of them interaction between members of the watchkeeping duty occurs. Moreover, each watch $Q$ is divided in a given transition $t$ into subgroups $(Q, j)(t), j \in J^{Q}$, according to strategies in a given period, therefore, the subgroups are represented as $N_{j}^{Q}(t)$, and its number in the designated period is $N^{Q}(t)$.

The behavior of watch members $Q$ forms $\xi^{Q}(t)=\left(\xi_{j}^{Q}(t)=\frac{N_{j}^{Q}(t)}{N^{Q}(t), j \in J^{Q}}\right)$ - distribution by strategy, and the cumulative behavior of watchmen in the given period is described by the set $\xi(t)=\left(\xi^{Q}(t), Q \in I\right)$.

The result of the interaction in the period $t$ is characterized by the vector $f(t)=\left(f_{j}^{Q}(t)\right), Q \in I, j \in J^{Q}$, where $f_{j}^{Q}$ defines the outcome of the solution of the micro-problem for the group $(Q, j)$. Next it is necessary to indicate the dependence of $f_{j}^{Q} f_{j}^{Q}$ on the conditions in the form of a distribution according to strategies of behavior $-\xi(t)$; weather conditions, visibility, intensity of navigation, proximity to navigational hazards $-z(t)$, as well as technical parameters whose totality is denoted by $q(t)$. This totality can include the numbers $N^{L}(t)$, time $t$, etc. Thus, the behavior of the watchkeeping duty in the long term will be described by the following dependence:

$$
\xi(t+1)=G\left(\{\xi(\tau), f(\tau), z(\tau), q(\tau)\}_{\tau \leq t}\right)
$$

In real conditions, the composition of the watch duty $Q \in I$ is constant, in turn, members of the watchkeeping duty change their strategies depending on the tasks, adapting to the conditions of interaction with the aim of maximizing $f_{j}^{Q}(t)$. During the duty, each watch member compares the strategy $i$ and the strategy $j$ with respect to the interaction partner, possibly subconsciously choosing the more effective one: $f_{j}^{Q}(t)>f_{i}^{Q}(t)$ regardless of the composition of the watch.

The performance loss from the initially chosen strategy $i$, leads to the choice of strategy $j$.

This is a significant problem because individual members of the team will form stable coalition relationships of interactions, which violates the watchkeeping instructions.

In the conditions that the recruitment of the watch-keeping personnel on a vessel is of an accidental nature, we get:

$$
u\left(f_{j}^{Q}(t)-f_{i}^{Q}(t)\right), u(0)=0
$$

Then:

$N_{i}^{Q}(t+1)=$

$$
=\sum_{r \in J} u\left(f_{i}^{Q}(t)-f_{r}^{Q}(t)\right) N_{r}^{Q}(t) N_{i}^{Q}(t) / N^{Q}
$$

The forecast of the state of carrying the watch on the passage at time $t+1$ will be:

$$
\xi_{i}^{Q}(t+1)=\sum_{r} u\left(f_{i}^{Q}(t)-f_{r}^{Q}(t)\right) \xi_{r}^{Q}(t), i \in J^{Q} .
$$

Thus, there is a problem of inconsistency and spontaneous replacement of the watchkeeping personnel by the mate, which violates the instructions and reduces the safety level. During simulator practice is an imbalance in training useful skills among cadets during the training practice. Passive members of the watchkeeping service do not learn 
the necessary practical skills, but active ones do this in overabundance.

The situation is complicated by the fact that for the laying and passage of a new route the composition of the watch team is formed randomly and there is a possibility of recruiting cadets who do not have the necessary skills, which will lead to the task failure.

When maneuvers are carried out in real conditions, the security threat increases significantly and can lead to catastrophic consequences.

In order to clarify the facts of the negative manifestation of the human factor, it is recommended to use the means of diagnosing the psychoemotional state of navigators in the form of Smart Watch. Synchronization of data from Smart Watch is displayed in the program interface (Fig. 8.). Complex use of software and hardware will allow the most accurate localization of individual human factor manifestations in maritime transport.

\section{Originality and practical value}

The authors for the first time developed software and hardware for analyzing the movements of members of the watchkeeping service, allowing identifying violations of safety regulations. As a result, a hardware-software complex for identifying the location and psychophysiological parameters of navigators was developed. Exceeding the temperature and heart rate of navigators, as well as fast moving of individual members of the watchkeeping service to the positions of other team members, testifies the violation of watchkeeping instructions. The automatic identification of these manifestations will prevent the negative manifestations of the human factor of the team, both in the course of simulator practice, and in the real situation.

\section{Conclusions}

Based on the results of the simulation, it can be concluded that, regardless of the composition and functional duties of the watchkeeping personnel, navigators with the highest qualifications tend to interact with the most experienced members of the watch, which significantly affects the safety level in maritime transport. However, the selection of the team consisting of the most qualified and experienced navigators in practice are not possible. The developed software and hardware complex will allow preventing undesirable interactions and objectively assessing the fulfillment of tasks by cadets during the simulator practice. It will also be possible to classify and form the members of the watchkeeping service in relation to the same qualifications, which will reduce the risk of unwanted interactions.

\section{LIST OF REFERENCE LINKS}

1. Бень, А. П. Людський фактор в автоматизованих системах управління судном та шляхи зниження його впливу / А. П. Бень // Наук. вісн. Херсон. держ. морс. акад. - 2012. - № 2 (7). - С. 26-30.

2. Каминский, В. Ю. Методика учёта профессионально-ценностного аспекта действий судоводителя во время тренажёрной подготовки / В. Ю. Каминский, М. Л. Маринов, Д. А. Скороходов // Морские интеллектуальные технологии. - 2018. - Т. 1, № 1 (39). - С. 209-214.

3. Косенко, Ю. І. Система ідентифікації функціональної ентропії суб’єкта критичної інфраструктури / Ю. І. Косенко, С. В. Рослякова, П. С. Носов // Современные направления теоретических и прикладных исследований : сб. науч. тр. по матер. Междунар. науч.-практ. интернет-конф. (19-30 марта 2013 г.). Одеса, 2013. - Т. 8 : Технические науки. - С. 50-54.

4. A new hybrid approach to human error probability quantification-applications in maritime operations / Y. T. Xi, Z. L. Yang, Q. G. Fang, W. J. Chen, J. Wang // Ocean Engineering. - 2017. - Vol. 138. - P. $45-54$. doi: 10.1016/j.oceaneng.2017.04.018

5. Arslan, O. Effects of Fatigue on Navigation Officers and SWOT Analyze for Reducing Fatigue Related Human Errors on Board / O. Arslan, I. D. Er // TransNav, the Intern. Journal on Marine Navigation and Safety of Sea Transportation. - 2007. - Vol. 1, No. 3. - P. 345-349.

6. Berg, H. P. Human Factors and Safety Culture in Maritime Safety (revised) / H. P. Berg // TransNav, the International Journal on Marine Navigation and Safety of Sea Transportation. - 2013. - Vol. 7. - Iss. 3. P. 343-352. doi: 10.12716/1001.07.03.04

7. Can We Learn from Aviation: Safety Enhancements in Transport by Achieving Human Orientated Resilient Shipping Environment / O. Turan, R. E. Kurt, V. Arslan [et al.] // Transportation Research Procedia. - 2016. Vol. 14. - P. 1669-1678. doi: 10.1016/j.trpro.2016.05.132 
8. Dixena, D. Application of Case-Based Reasoning for Ship turning Emergency to prevent Collision / D. Dixena, B. Chakraborty, N. Debnath // 9th IEEE Intern.1 Conference on Industrial Informatics (26-29 July 2011). - Lisbon, 2011. doi: 10.1109/indin.2011.6034956

9. Flow networks: A characterization of geophysical fluid transport / Enrico Ser-Giacomi, Vincent Rossi, Cristóbal López, Emilio Hernández-García // Chaos: An Interdisciplinary Journal of Nonlinear Science. - 2015. Vol. 25. - Iss. 3. doi: 10.1063/1.4908231

10. Jech, T. Set theory / T. Jech. - Berlin ; Heidelberg : Springer, 1997. - 243 p. doi: 10.1007/3-540-44761-X

11. Lazarowska, A. Safe ship control method with the use of ant colony optimization / A. Lazarowska // Solid State Phenomena. - 2014. - Vol. 210. - P. 234-244. doi: 10.4028/www.scientific.net/SSP.210.234

12. Magnus, W. Combinatorial group theory: presentation of groups in terms of generators and relations / W. Magnus, A. Karrass, D. Solitar. - New York : Dover Publications. - 1976. - 464 p.

13. Osekowska, E. Potential Fields in Modeling Transport over Water / E. Osekowska, S. Axelsson, B. Carlsson // Transport of Water versus Transport over Water. - Cham : Springer, 2015. - P. 259-280. doi: 10.1007/978-3-319-16133-4_14

14. Özdemir, Ü. Strategic approach model for investigating the cause of maritime accidents / Ü. Özdemir, A. Güneroğlu // PROMET-Traffic\&Transportation. - 2015. - Vol. 27. - Iss. 2. - P. 113-123. doi: $10.7307 /$ ptt.v27i2.1461

15. The Psychological General Well-Being Index (PGWBI) for assessing stress of seafarers on board merchant ships / A. Carotenuto, M. F. Angiola, M. Ivana, F. Sibilio, A. Saturnino, E. Traini, F. Amenta // International Maritime Health. - 2013. - Vol. 64. - Iss. 4. - P. 215-220. doi: 10.5603/IMH.2013.0007

16. Understanding the outcome in the chinese changjiang disaster in 2015: a retrospective study / C. Yang, J. Gao, J. Du, H. Y. Wang, J. X. Jiang, Z. G. Wang // The Journal of Emergency Medicine. - 2017. - Vol. 52. - Iss. 2. - P. 197-204. doi: 10.1016/j.jemermed.2016.08.013

17. Zhang, L. Analyzing Human Error in Maritime Transportation in China Based on Game Theory / L. Zhang, J. Lu, Y. Ai // Journal of Wuhan University of Technology (Transportation Science \& Engineering). - 2014. Vol. 6. - P. 1282-1290. doi: 10.3963/j.issn.2095-3844.2014.06.022

\title{
П. С. НОСОВ ${ }^{1 *}$, І. В. ПАЛАМАРЧУК $2^{*}$, М. С. САФОНОВ ${ }^{3 *}$, В. I. НОВИКОВ ${ }^{4 *}$
}

\begin{abstract}
1*Каф. «Судноводіння та електронні навігаційні системи», Херсонська державна морська академія, просп. Ушакова, 20, Херсон, Україна, 73000, тел. +38 (050) 90906 08, ел. пошта pason@ukr.net, ORCID 0000-0002-5067-9766

2*Каф. «Судноводіння та електронні навігаційні системи», Херсонська державна морська академія, просп. Ушакова, 20, Херсон, Україна, 73000, тел. +38 (050) 90906 08, ел. пошта pason@ukr.net, ORCID 0000-0001-9161-1592

3*Каф. «Комп’ютерна інженерія та інженерія програмного забезпечення», Одеський національний політехнічний університет, Херсонський політехнічний коледж, вул. Небесної сотні, 23, Херсон, Україна, 73000, тел. +38 (066) 24581 85, ел. пошта nemko85@gmail.com, ORCID 0000-0001-9742-8270

${ }^{4 *}$ Каф. «Суднове машинобудування й енергетика», Національний університет кораблебудування імені адмірала Макарова, Херсонська філія, просп. Ушакова, 44, Херсон, Україна, 73022, тел. +38 (095) 36567 08, ел. пошта vertigogo@i.ua, ORCID 0000-0002-1823-4919
\end{abstract}

\section{МОДЕЛЮВАННЯ ПРОЯВІВ ЛЮДСЬКОГО ФАКТОРА У КОМАНДИ МОРСЬКОГО ТРАНСПОРТНОГО ЗАСОБУ}

Мета. У статті передбачається дослідити траєкторії переміщення членів вахтової команди на морському транспорті, що призводять до зниження рівня безпеки. Метою дослідження є розробка формального апарату, а також програмно-апаратних засобів ідентифікації розташування членів вахтової команди під час виконання складних маневрів. Методика. У ході побудови математичної моделі були розглянуті найбільш поширені схеми взаємодії членів вахти в момент виконання складних маневрів. Загальна задача була розглянута як серія вахтових взаємодій для вирішення мікрозадач управління судном на певний момент. У результаті імітаційного моделювання визначено, що ключову роль виконує перший помічник капітана, який з найбільшою ймовірністю схильний відхилитися від інструкцій через надмірну активність або пасивність у діях. Також розглянуті моделі взаємодії членів вахтової служби в рамках багатоденного переходу судна. Результати. Дослідження свідчить, що утворення сталих взаємодій залежить від рівня досвіду й кваліфікації членів вахтової служби. Надмірно активне переміщення помічника капітана, а також дублювання функцій окремих членів вахтової служби негативно впливає на рівень безпеки під час управління судном. Запро- 
поновано програмно-апаратні засоби, що дозволяють ідентифікувати розташування й переміщення членів вахтової команди, які призводять до відхилень від інструкцій несення вахти на морському транспорті. Наукова новизна. Уперше були розроблені програмно-апаратні засоби для аналізу переміщень членів вахтової служби, що дозволяють ідентифікувати порушення посадових інструкцій. Практична значимість. На основі розроблених програмно-апаратних засобів ідентифікації розташування й переміщення членів вахтової команди з'являється можливість більш ефективно оцінювати дії курсантів-судноводіїв під час проходження практики на базі навігаційного тренажера NTPRO 5000 у Херсонській державній морській академії, Україна. Ці дослідження також можуть бути корисними під час вивчення дисципліни «Організація дій екіпажу в екстремальних умовах».

Ключові слова: людський фактор; модель поведінки; взаємодія членів команди; позаштатні ситуації

\title{
П. С. НОСОВ ${ }^{*}$, И. В. ПАЛАМАРЧУК ${ }^{2 *}$, М. С. САФОНОВ ${ }^{3 *}$ В. И. НОВИКОВ ${ }^{4 *}$
}

\begin{abstract}
${ }^{1 *}$ Каф. «Судовождение и электронные навигационные системы», Херсонская государственная морская академия, просп. Ушакова, 20, Херсон, Украина, 73000, тел. +38 (050) 90906 08, эл. почта pason@ukr.net, ORCID 0000-0002-5067-9766

${ }^{2 *}$ Каф. «Судовождение и электронные навигационные системы», Херсонская государственная морская академия, просп. Ушакова, 20, Херсон, Украина, 73000, тел. +38 (050) 90906 08, эл. почта pason@ukr.net, ORCID 0000-0001-9161-1592

$3^{3 *}$ Каф. «Компьютерная инженерия и инженерия программного обеспечения», Одесский национальный политехнический университет, Херсонский политехнический колледж, ул. Небесной сотни, 23, Херсон, Украина, 73000, тел. +38 (066) 24581 85, эл. почта nemko85@gmail.com, ORCID 0000-0001-9742-8270

4*Каф. «Судовое машиностроение и энергетика», Национальный университет кораблестроения имени адмирала Макарова, Херсонский филиал, просп. Ушакова, 44, Херсон, Украина, 73022, тел. +38 (095) 36567 08, эл. почта vertigogo@i.ua, ORCID 0000-0002-1823-4919
\end{abstract}

\section{МОДЕЛИРОВАНИЕ ПРОЯВЛЕНИЙ ЧЕЛОВЕЧЕСКОГО ФАКТОРА У КОМАНДЫ МОРСКОГО ТРАНСПОРТНОГО СРЕДСТВА}

Цель. В статье предполагается исследовать траектории перемещения членов вахтенной команды на морском транспорте, приводящие к снижению уровня безопасности. Целью исследования является разработка формального аппарата, а также программно-аппаратных средств идентификации расположения членов вахтенной команды во время выполнения сложных маневров. Методика. В ходе построения математической модели были рассмотрены наиболее распространенные схемы взаимодействия членов вахты в момент выполнения сложных маневров. Общая задача была рассмотрена как серия вахтенных взаимодействий для решения микрозадач управления судном на определенный момент. В результате имитационного моделирования определено, что ключевую роль выполняет первый помощник капитана, который с наибольшей вероятностью подвержен отклониться от инструкций ввиду чрезмерной активности или пассивности в действиях. Также рассмотрены модели взаимодействия членов вахтенной службы в рамках многодневного перехода судна. Результаты. Исследование свидетельствует, что образование устоявшихся взаимодействий зависит от уровня опыта и квалификации членов вахтенной службы. Чрезмерно активное перемещение помощника капитана, а также дублирование функций отдельных членов вахтенной службы негативно влияет на уровень безопасности при управлении судном. Предложены программно-аппаратные средства, позволяющие идентифицировать расположение и перемещение членов вахтенной команды, указывающие на отклонения от инструкций несения вахты на морском транспорте. Научная новизна. Впервые разработаны программноаппаратные средства для анализа перемещений членов вахтенной службы, позволяющие идентифицировать нарушения должностных инструкций. Практическая значимость. На основе разработанных программноаппаратных средств идентификации расположения и перемещения членов вахтенной команды появляется возможность более эффективно оценивать действия курсантов-судоводителей при прохождении практики на базе навигационного тренажера NTPRO 5000 в Херсонской государственной морской академии, Украина. Данные исследования также могут быть полезными при изучении дисциплины «Организация действий экипажа в экстремальных условиях».

Ключевые слова: человеческий фактор; модель поведения; взаимодействие членов команды; внештатные ситуации 


\section{REFERENCES}

1. Ben, A. P. (2012). Liudskyi faktor v avtomatyzovanykh systemakh upravlinnia sudnom ta shliakhy znyzhennia yoho vplyvu. The Scientific Bulletin of Kherson State Maritime Academy, 2(7), 26-30. (in Ukranian)

2. Kaminsky, V. Y. (2018). The treatment of professional-value aspect of action navigators during simulator training. Marine Intellectual Ttechnologies, 1(39), 209-214. (in Russian)

3. Kosenko, Y. I., Rosliakova, S. V., \& Nosov, P. S. (2013). Systema identyfikatsii funktsionalnoi entropii sub'iekta krytychnoi infrastruktury. Sovremennye napravleniya teoreticheskikh i prikladnykh issledovaniy: Sbornik nauchnykh trudov po materialam Mezhdunarodnoy nauchno-prakticheskoy Internet-konferentsii (1930 marta 2013 g.). (pp. 50-54). Odessa. (in Ukranian)

4. Xi, Y. T., Yang, Z. L., Fang, Q. G., Chen, W. J., \& Wang, J. (2017). A new hybrid approach to human error probability quantification-applications in maritime operations. Ocean Engineering, 138, 45-54. doi: 10.1016/j.oceaneng.2017.04.018 (in English)

5. Arslan, O. (2007). Effects of Fatigue on Navigation Officers and SWOT Analyze for Reducing Fatigue Related Human Errors on Board. TransNav, the International Journal on Marine Navigation and Safety of Sea Transportation, 1(3). 345-349. (in English)

6. Berg, H. P. (2013). Human Factors and Safety Culture in Maritime Safety (revised). TransNav, the International Journal on Marine Navigation and Safety of Sea Transportation, 7(3), 343-352. doi: 10.12716/1001.07.03.04 (in English)

7. Turan, O., Kurt, R. E., Arslan, V., Silvagni, S., Ducci, M., Liston, P., ... Papadakis, G. (2016). Can We Learn from Aviation: Safety Enhancements in Transport by Achieving Human Orientated Resilient Shipping Environment. Transportation Research Procedia, 14, 1669-1678. doi: 10.1016/j.trpro.2016.05.132 (in English)

8. Dixena, D., Chakraborty, B., \& Debnath, N. (2011). Application of Case-based reasoning for ship turning emergency to prevent collision. 2011 9th IEEE International Conference on Industrial Informatics. Lisbon. doi: 10.1109/indin.2011.6034956 (in English)

9. Ser-Giacomi, E., Rossi, V., López, C., \& Hernández-García, E. (2015). Flow networks: A characterization of geophysical fluid transport. Chaos: An Interdisciplinary Journal of Nonlinear Science, 25(3). doi: 10.1063/1.4908231 (in English)

10. Jech, T. (2003). Set Theory. Berlin; Heidelberg: Springer. doi: 10.1007/3-540-44761-X (in English)

11. Lazarowska, A. (2013). Safe Ship Control Method with the Use of Ant Colony Optimization. Solid State Phenomena, 210, 234-244. doi: 10.4028/www.scientific.net/SSP.210.234 (in English)

12. Magnus, W., Karrass, A., \& Solitar, D. (1976). Combinatorial group theory: presentation of groups in terms of generators and relations. New York: Dover Publications. (in English)

13. Osekowska, E., Axelsson, S., \& Carlsson, B. (2015). Potential Fields in Modeling Transport over Water. Transport of Water Versus Transport over Water (pp. 259-280). Cham: Springer. doi: 10.1007/978-3-319-16133-4_14 (in English)

14. Özdemir, Ü., \& Güneroğlu, A. (2015). Strategic Approach Model for Investigating the Cause of Maritime Accidents. PROMET-Traffic\&Transportation, 27(2), 113-123. doi: 10.7307/ptt.v27i2.1461 (in English)

15. Carotenuto, A., Fasanaro, A. M., Molino, I., Sibilio, F., Saturnino, A., Traini, E., \& Amenta, F. (2013). The Psychological General Well-Being Index (PGWBI) for assessing stress of seafarers on board merchant ships. International Maritime Health, 64(4), 215-220. doi: 10.5603/imh.2013.0007 (in English)

16. Yang, C., Gao, J., Du, J., Wang, H., Jiang, J., \& Wang, Z. (2017). Understanding the Outcome in the Chinese Changjiang Disaster in 2015: A Retrospective Study. The Journal of Emergency Medicine, 52(2), $197-204$. doi: 10.1016/j.jemermed.2016.08.013 (in English)

17. Zhang, L., Lu, J., \& Ai, Y. (2014). Analyzing Human Error in Maritime Transportation in China Based on Game Theory. Journal of Wuhan University of Technology (Transportation Science \& Engineering), 6, $1282-$ 1290. doi: 10.3963/j.issn.2095-3844.2014.06.022 (in English)

Received: March 29, 2016

Accepted: July 29, 2016 